\title{
The seasonal entrance of Penaeus setiferus and Penaeus duorarum postlarvae into Términos Lagoon, Campeche, México
}

\author{
Araceli Puentes-Salazar ${ }^{1}$, Pedro Cervantes-Hernandez ${ }^{2}$ \& Mario A. Gómez-Ponce $^{3}$ \\ ${ }^{1}$ Postgrado en Ecología Marina, Universidad del Mar, Puerto Ángel, Oaxaca, México \\ ${ }^{2}$ Instituto de Recursos, Universidad del Mar, Puerto Ángel, Oaxaca, México \\ ${ }^{3}$ Instituto de Ciencias del Mar y Limnología, Estación El Carmen \\ Universidad Nacional Autónoma de México, Campeche, México \\ Corresponding author: Pedro Cervantes-Hernández (pch@ angel.umar.mx)
}

\begin{abstract}
This study establishes the season for the immigration (recruitment) of Penaeus setiferus and P. duorarum postlarvae into Términos Lagoon, México, as well as the hydrological conditions that occur during this event. The abundance of postlarvae of both species was used to infer the reproductive period for each species. The zooplankton collection was carried out monthly for three years. The nets used were $50 \mathrm{~cm}$ in diameter, $1.5 \mathrm{~m}$ in length and $505 \mu \mathrm{m}$ mesh size, and temperature and salinity were measured with an YSI. The fluvial discharges were taken from Comisión Nacional del Agua (CONAGUA). The harmonic pattern variation (HPV) was analyzed for each variable (density of postlarvae, salinity, temperature and fluvial discharge). A cycle was analyzed and divided into two episodes (rise and descent) to estimate the HPV of each postlarval species. The entrance of both postlarval species starts from June to September, with higher density in August, which decreases from October to May, with the lowest density in March. The first episode was established from June to August and the second episode in September. During the first episode the hydrological conditions were: high salinity $(34)$, a warm temperature $\left(30^{\circ} \mathrm{C}\right)$ and low accumulated fluvial discharge $\left(2,828 \mathrm{~m}^{3} \mathrm{~s}^{-1}\right)$, while, in the second, they were low salinity $(28)$, a moderately warm temperature $\left(29^{\circ} \mathrm{C}\right)$ and high accumulated fluvial discharge $\left(3,934 \mathrm{~m}^{3} \mathrm{~s}^{-1}\right)$.
\end{abstract}

Keywords: Penaeus setiferus; Penaeus duorarum; white shrimp; pink shrimp; recruitment; reproduction

\section{INTRODUCTION}

The shrimp is an important economic resource in México, and throughout the Gulf of México, the main shrimp fishery sectors are located in TamaulipasVeracruz and Campeche Bank (Bank, where the Términos Lagoon is located. The brown shrimp (Penaeus aztecus Ives, 1891) is caught at the first location. The white shrimp Penaeus setiferus (Linnaeus, 1767) and pink shrimp Penaeus duorarum Burkenroad, 1939 are caught at the second location (Gracia, 2004).

In the Gulf of México, the shrimp fishery was founded in 1950, and in 1972 the maximum catch recorded was 20,000 t (Ramírez-Rodríguez et al., 2006). Recently, the shrimp catch level was documentted at 12,973 $\mathrm{t}$ (CONAPESCA, 2016). At first, the shrimp fishery had neither catch regulations nor a closure system (Cervantes-Hernández \& Gracia, 2011). Due to its growing exploitation, in 1993, a closure season was instituted throughout the Gulf of México (from May to August with modifications until September-October) (SAGARPA-INP, 2012). Before 1993, the Mexican government had extensive records about the commercial shrimp catch, classified by categories (shrimp abundance separated by age groups), and this information was used to monitor the shrimp fishery with studies on mortality, exploitation evaluations and verifications of closure (CervantesHernández, 1999, 2015; Cervantes-Hernández \& Gracia, 2011). In the Tamaulipas-Veracruz sector, the mentioned catch type $P$. aztecus reproductive and recruitment seasons were documented from 1974 to

Corresponding editor: Mauricio Laterça 
1992 (Cervantes-Hernández, 2015). With similar catch information, Cervantes-Hernández (2008) documented Farfantepenaeus californiensis (Holmes, 1900) reproductive and recruitment seasons in the Gulf of Tehuantepec. Cervantes-Hernández (2008) concluded that the commercial shrimp catch, classified by categories, is an excellent marine recourse for monitoring the shrimp fishery and delimiting shrimp reproductive and recruitment seasons.

When closures began to work in the Gulf of México, the Mexican government stopped recording the commercial shrimp catch, classified by categories, and updates to the studies mentioned above were discontinued. For this reason, different authors implemented other study methods to delimit shrimp reproductive seasons. According to Gracia \& Soto (1990), FloresCoto et al. (2018) and Gómez-Ponce et al. (2018), reproductive seasonality can be indirectly documented with estimations of the density of shrimp postlarvae that enters lagoon systems.

For our study period, the shrimp commercial catch record classified by categories does not exist. For this reason, the shrimp postlarvae entrance into Términos Lagoon was used to delimit $P$. setiferus and $P$. duorarum reproductive seasons. Hydrologic information was used to describe prevalent lagoon conditions during shrimp postlarvae entrance.

The objective is to establish the postlarvae recruitment season of $P$. setiferus and $P$. duorarum in the Términos Lagoon, as well as the reproductive season of these species in the Campeche Bank. This study complements other studies on $P$. setiferus and $P$. duorarum reproductive seasons in the Gulf of México. Additionally, cases of shrimp reproductive seasons, documented in the shrimp commercial catch record, classified by the categories of $P$. setiferus, $P$. duorarum and $F$. californiensis, were examined.

\section{MATERIALS AND METHODS}

\section{Fieldwork}

For the present study, from to 2010 at 2012, technical personnel from ICMyL, UNAM, sampled Penaeus setiferus and $P$. duorarum postlarvae in the Puerto Real Inlet $\left(18^{\circ} 46^{\prime} 46.40^{\prime \prime} \mathrm{N}, 9^{\circ} 30^{\prime} 1.55^{\prime \prime} \mathrm{W}\right)$ located in Términos Lagoon, México (Fig. 1). For catching postlarvae, a special device was used, and it incorporated three CALCOFI trapeze-type nets placed on the surface $(1 \mathrm{~m})$, at mid-water $(4 \mathrm{~m})$, and the bottom $(9 \mathrm{~m})$. Each net has a $50 \mathrm{~cm}$ mouth diameter, $1.5 \mathrm{~m}$ total length, and a $505 \mu \mathrm{m}$ mesh size (Flores-Coto \& Zavala-García, 1994). The device was placed with ballast at the bottom of the lagoon and secured to one of the Puerto Real bridge columns via parallel cables. In the field, collected postlarvae were preserved in $4 \%$ formalin (neutralized with sodium borate).

\section{Reproductive seasons}

In the laboratory, postlarvae were transferred to bottles with $70 \%$ alcohol. According to Ringo \& Zamora (1968) and Subrahmanyam (1971), postlarvae were separated and identified as P. setiferus or P. duorarum. For the three depth levels, postlarvae density was estimated $\times 100 \mathrm{~m}^{3}$ of filtered water (Table 1). This information was used to establish the total postlarvae density that entered monthly into Términos Lagoon. Based on this information, the two-time series was composed, and named $P$. setiferus postlarvae density (Ps) and $P$. duorarum postlarvae density (Pd), respectively.

The mentioned time series were analyzed via the CENSUS method in order to estimate the harmonic pattern variation (HPV) (referred to as the seasonal factor in Statistica 7.0 software) (Cervantes-Hernández et al., 2016). HPV is a mathematical application used to detect, from Ps and Pd time series, monthly cyclical anomalies of equal magnitudes (cycle height) and amplitudes (cycle width). These monthly cyclical anomalies can be positive or negative, with the zero value as the midpoint of change. Positive cyclical anomalies represented the increases in postlarvae entrance into Términos Lagoon, and negative cyclical anomalies represented the decreases. The positive cyclical anomalies were explicitly used to describe when postlarvae started to arrive, reached their maximum density, and finished entering Términos Lagoon. In this study, HPV were named as follows: HPV-Ps for P. setiferus postlarvae density and HPV-Pd for $P$. duorarum postlarvae density.

\section{Hydrologic information}

During the postlarvae sampling in Puerto Real Inlet, monthly salinity and lagoon water temperatures were recorded at the three depth levels. Additionally, we used fluvial discharge records from the Candelaria, Chumpan, and Palizada rivers (in $\mathrm{m}^{3} \mathrm{~s}^{-1}$ ) provided by the Government Agency CONAGUA in Campeche State.

The salinity and the lagoon water temperature were averaged monthly, considering the three depth levels. With that information and the monthly accumulate fluvial discharge, three-time series were composed. Each time series was analyzed via the Census method to estimate their corresponding HPV. The increases in salinity, lagoon water temperature and accumulate fluvial discharge were represented by positive cyclical 


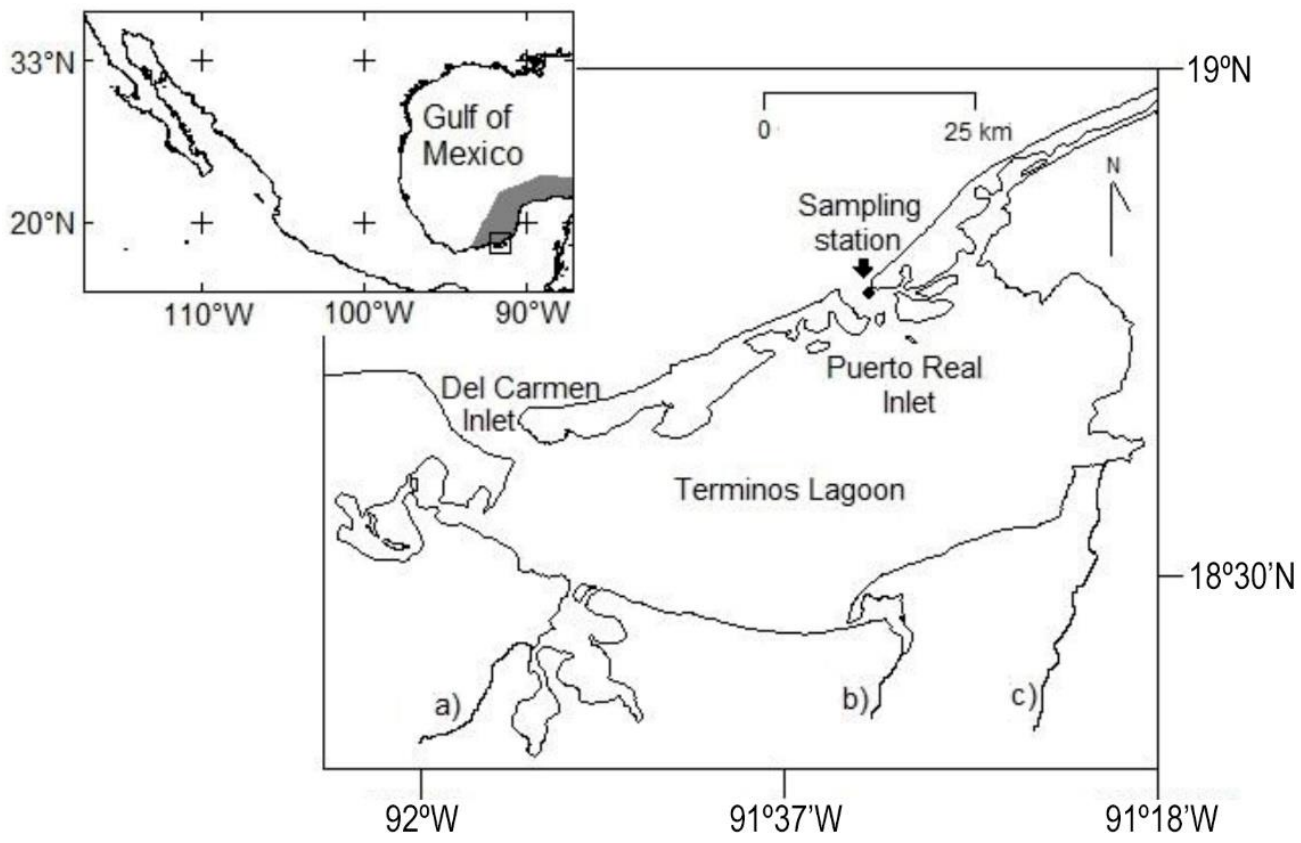

Figure 1. The geographical location of Términos Lagoon. Campeche Bank sector (grey area), a) Palizada, b) Chumpam and c) Candelaria rivers. Single sampling station (black point).

anomalies. Additionally, the respective decreases were represented by negative cyclical anomalies. The positive cyclical anomalies were specifically used to describe internal lagoon conditions during the entrance of shrimp postlarvae.

In this study, the aforementioned HPV were named as the following: HPV-salinity, HPV-lagoon water temperature, and HPV-accumulate fluvial discharge, respectively.

\section{Multiple correlations}

Once HPV-Ps and HPV-Pd were estimated, a complete postlarvae entrance cycle was identified and taken as reference to explain the other found cycles in the study period. The cycle of reference was divided into two sections. The first section was established from initial to maximum postlarvae entrance the first postlarvae entrance episode, and the second section was established from after maximum until the end of the postlarvae entrance the second postlarvae entrance episode. Finally, for each postlarvae entrance episode, the following HPV time series were statistically correlated: Ps, Pd, salinity, lagoon water temperature and accumulate fluvial discharge. The Statistica 7.0 software performed the correlation process.

\section{RESULTS}

\section{Reproductive seasons and postlarvae entrance}

In average, the positive cyclical anomalies of the HPVPs and HPV-Pd showed that Penaeus setiferus and $P$. duorarum postlarvae entered Términos Lagoon annually from June to September, with the highest density of postlarvae entrance occurring in August (Fig. 2). The corresponding negative cyclical anomalies showed that each year postlarvae entrance decreased from October to May, and the lowest density of postlarvae entrance was recorded during March (Fig. 2).

For both shrimp species, the first postlarvae entrance cycle was used as reference, and this was divided into two sections from June to August (the first postlarvae entrance episode), and the complete month of September (the first postlarvae entrance episode) (Fig. 2). The aforementioned was equally taken into account for other found years.

An analysis more detail on the positive cyclical anomalies of the HPV-Ps and HPV-Pd signals suggests that both species of shrimp postlarvae did not enter lagoon environment at the same time. In the case of $P$. setiferus, its postlarvae entered from early June to late September. In the case of $P$. duorarum, its postlarvae entered from middle June to middle September. So, it was detected that there is a difference of 15 days between the postlarvae entrance of both shrimp species (Fig. 2).

\section{Hydrologic information}

Estimated hydrologic HPV time series are shown in Figure 3. 


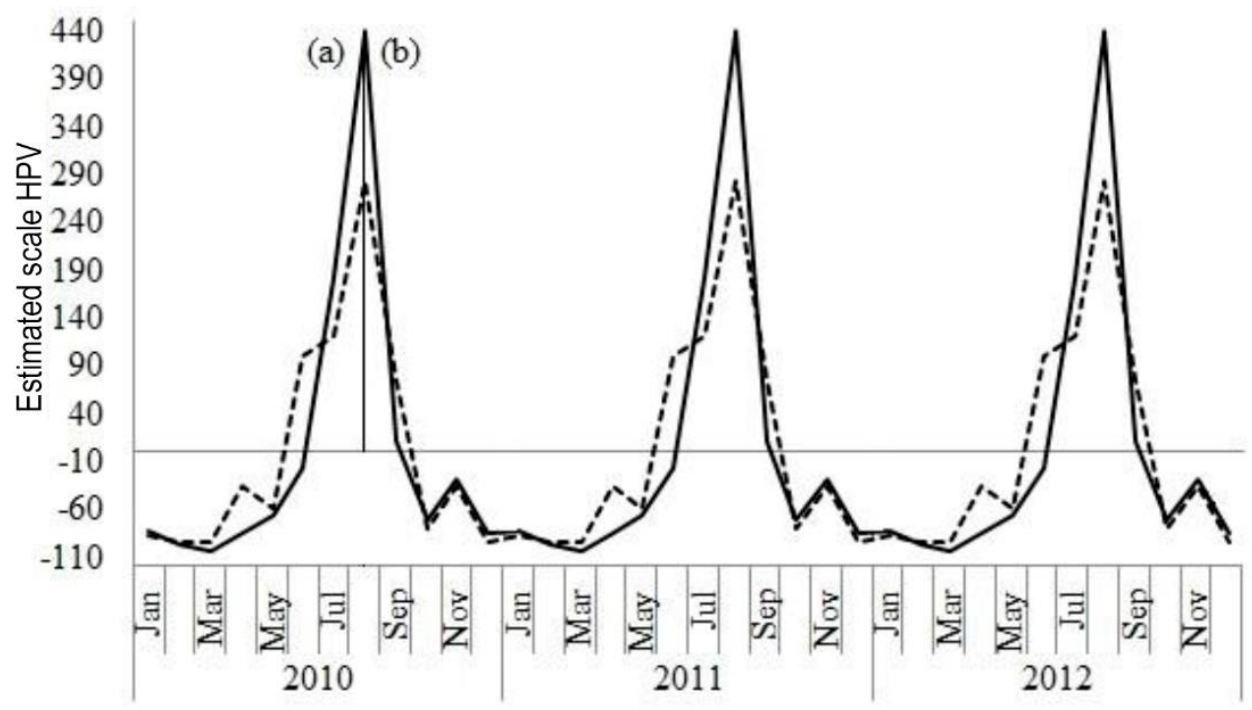

Figure 2. Harmonic pattern variations (HPV) of Penaeus setiferus postlarvae density (HPV-Ps, discontinuous line) and $P$. duorarum postlarvae density (HPV-Pd, black line). The estimated range for positive cyclical anomalies was from 1 to 440, and in the case of negative cyclical anomalies, it was between -1 and -110: the first postlarvae entrance episode (a) and the second postlarvae entrance episode (b).

A highest postlarvae density on entrance into Términos Lagoon during was recorded during the first episodes (Table 1, Fig. 2). In this case, prevalent hydrologic lagoon conditions were high salinity (34), a warm lagoon temperature $\left(30^{\circ} \mathrm{C}\right)$, and low accumulate fluvial discharge $\left(2,828 \mathrm{~m}^{3} \mathrm{~s}^{-1}\right)$ (Table 1, Fig. 3).

A lowest postlarvae density on entrance into Términos Lagoon was recorded during the second episode (Table 1, Fig. 2). In this case, prevalent hydrologic lagoon conditions were low salinity (28), a moderately warm lagoon temperature $\left(29^{\circ} \mathrm{C}\right)$, and high accumulate fluvial discharge $\left(3,934 \mathrm{~m}^{3} \mathrm{~s}^{-1}\right)$ (Table 1 , Fig. 3).

\section{Muliple correlations between the HPV time series}

In the first postlarvae entrance episode, Ps and Pd showed direct correlations with salinity $(r=0.46$ and $r$ $=0.86$, respectively), lagoon water temperature $(\mathrm{r}=$ 0.90 and $\mathrm{r}=0.99$, respectively) and accumulate fluvial discharge $(r=0.38$ and $r=0.82$, respectively). All correlation cases resulted statistical not significance $(P$ $>$ 0.05). Additionally, $\mathrm{Ps}$ and $\mathrm{Pd}$ showed direct correlation $(\mathrm{r}=0.84, P>0.05)$.

In the second postlarvae entrance episode, $\mathrm{Ps}$ and $\mathrm{Pd}$ showed inverse correlations with salinity $(\mathrm{r}=-0.99(P$ $<0.05)$ and $\mathrm{r}=-0.76(P>0.05)$, respectively), lagoon water temperature $(\mathrm{r}=-0.99$ and $\mathrm{r}=-0.77$, respectively, $P>0.05)$, and accumulate fluvial discharge $(\mathrm{r}=-0.72$ $(P>0.05)$ and $\mathrm{r}=-0.99(P<0.05)$, respectively). Additionally, Ps and Pd showed direct correlation ( $\mathrm{r}=$ $0.71, P>0.05)$.

\section{DISCUSSION}

In the first study performed in Términos Lagoon, it was documented that Penaeus setiferus and $P$. duorarum postlarvae have an entrance massive episode in the year. This episode was established from June to September, with maximum postlarvae entrance in July and November 1979, and in June 1980 (Gracia \& Soto, 1990). This study was performed with eleven months of sampling (from August to November 1979 and from February to August 1980). Additionally, the authors used shrimp commercial catch records, and they reported a greater abundance of $P$. setiferus spawners in the Campeche Bank sector from October to February (Fig. 4). In the case of P. setiferus, these circumstances are not consistent with each other because when its spawner abundance increases, the postlarvae entrance should be more significant. So, there should be a second postlarvae entrance episode during winter in Términos Lagoon.

\section{The first postlarvae entrance episode}

In complementary studies conducted in Términos Lagoon, Flores-Coto et al. (2018) and Gómez-Ponce et al. (2018), again documented the first postlarvae entrance episode mentioned by Gracia \& Soto (1990). These authors implemented nine months of sampling (between March and November 2010 and 2013, respectively), and they documented maximum $P$. setiferus and $P$. duorarum postlarvae entrance in June and in September 2013. Between those particular studies, 
Table 1. Monthly original Penaeus setiferus (Ps) and P. duorarum (Pd) postlarvae density records for $100 \mathrm{~m}^{-3}$ of filtered water. Monthly salinity (S) and water temperature of lagoon (WTL in ${ }^{\circ} \mathrm{C}$ ) recorded in Puerto Real Inlet. Monthly fluvial discharge (FD) records from the Candelaria, Chumpan and Palizada rivers in $\mathrm{m}^{3} \mathrm{~s}^{-1}$.

\begin{tabular}{lrrccc}
\hline & \multicolumn{1}{c}{ Ps } & \multicolumn{1}{c}{ Pd } & S & WTL & FD \\
\hline January & 58.10 & 5080.78 & 33.62 & 24.32 & 293.62 \\
February & 53.08 & 2577.79 & 34.88 & 23.77 & 213.05 \\
March & 48.05 & 74.83 & 36.15 & 23.23 & 219.33 \\
April & 6356.65 & 1067.46 & 36.60 & 27.26 & 240.07 \\
May & 7388.39 & 6266.50 & 36.47 & 30.35 & 233.40 \\
June & 38584.32 & 13158.10 & 36.48 & 31.17 & 247.41 \\
July & 34639.19 & 28959.60 & 31.98 & 29.98 & 306.69 \\
August & 33035.26 & 31142.05 & 32.49 & 29.10 & 332.59 \\
September & 31617.06 & 20384.66 & 22.82 & 29.87 & 329.60 \\
October & 754.44 & 630.69 & 26.78 & 27.91 & 328.54 \\
November & 3383.57 & 2290.85 & 26.43 & 25.81 & 305.64 \\
December & 2602.29 & 1793.06 & 28.66 & 25.86 & 250.77 \\
January & 1821.01 & 1295.28 & 30.88 & 25.90 & 210.25 \\
February & 1039.72 & 797.50 & 33.10 & 25.95 & 193.41 \\
March & 258.44 & 299.71 & 35.32 & 26.00 & 185.70 \\
April & 451.12 & 581.97 & 35.59 & 28.04 & 190.44 \\
May & 589.88 & 219.87 & 36.99 & 29.73 & 221.99 \\
June & 24021.15 & 12437.61 & 37.85 & 29.68 & 278.89 \\
July & 23939.04 & 54837.66 & 34.88 & 29.34 & 343.34 \\
August & 61100.34 & 105846.00 & 31.73 & 31.93 & 389.40 \\
September & 14181.07 & 11081.88 & 30.82 & 30.80 & 412.87 \\
October & 3710.28 & 1843.28 & 26.65 & 27.76 & 385.22 \\
November & 15304.02 & 13354.88 & 27.83 & 27.16 & 325.69 \\
December & 148.12 & 320.02 & 32.93 & 24.86 & 277.28 \\
January & 1827.17 & 2723.33 & 33.49 & 25.23 & 237.59 \\
February & 377.76 & 724.81 & 32.23 & 25.89 & 201.61 \\
March & 549.89 & 338.96 & 36.38 & 27.35 & 186.59 \\
April & 11211.80 & 4205.07 & 36.11 & 27.87 & 188.49 \\
May & 4025.05 & 6054.61 & 36.41 & 29.56 & 210.32 \\
June & 1848.65 & 2926.51 & 35.87 & 30.55 & 254.07 \\
July & 7134.27 & 2553.47 & 34.20 & 29.74 & 314.65 \\
August & 4443.48 & 15766.97 & 31.81 & 29.54 & 360.92 \\
September & 3471.91 & 2531.07 & 30.84 & 30.34 & 382.33 \\
October & 3500.97 & 13036.20 & 31.57 & 28.68 & 373.26 \\
November & 68.15 & 10086.72 & 31.09 & 25.41 & 338.31 \\
December & 63.13 & 7583.74 & 32.35 & 24.87 & 293.06 \\
\hline & & & & & \\
& & & &
\end{tabular}

the most significant differences were found for $P$. setiferus and $P$. duorarum postlarvae entrance dates, and these differences were partially explained concerning changes lagoon water temperature. FloresCoto et al. (2018) and Gómez-Ponce et al. (2018) concluded that most postlarvae entrance occurs from June to September (during the rainy season) when the lagoon water temperature is warm. Also, these authors mentioned that during the rest of the year, postlarvae entrance is reduced (from October to May).

In the present study, problems identifying entrance dates for the maximum entry influx of $P$. setiferus and
P. duorarum postlarvae were solved via HPV-Ps and HPV-Pd signals. Results showed that the entrance of $P$. setiferus and $P$. duorarum postlarvae into Términos Lagoon occurs from June to September (during the rainy season), with maximum postlarvae entrance occurring in August (Fig. 2). Additionally, postlarvae entrance decreased from October to May, and the lowest signal was recorded during March (Fig. 2). It was concluded that the annual cycleof postlarvae entrance is similar for both shrimp species, but itis important to recognize that a difference of 15 days was recorded in their arrival dates (Fig. 2). 


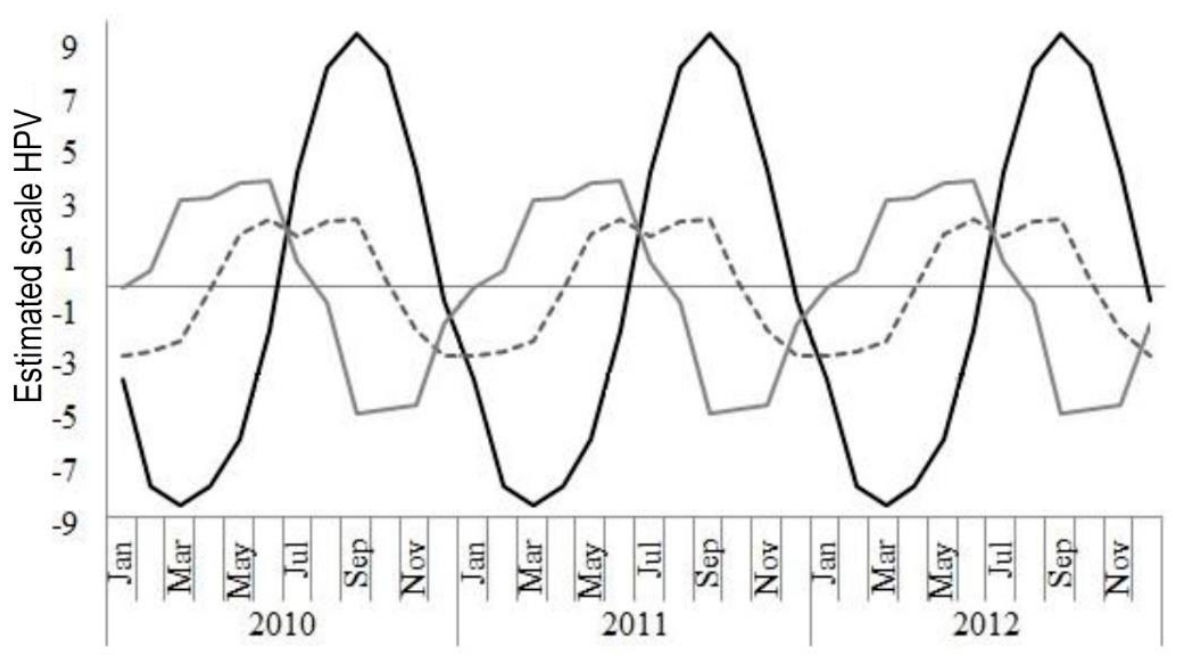

Figure 3. Harmonic pattern variations (HPV) for salinity (continuous gray line), lagoon water temperature (discontinuous gray line) and accumulate fluvial discharge (black line). The estimated range for positive cyclical anomalies was from 1 to 9 , and in the case of negative cyclical anomalies, it was between -1 and -9 .

When a complete postlarvae entrance cycle was divided into two sections, it was found that postlarvae entrance kept increasing while prevalent hydrological conditions were high salinity (34), a warm lagoon temperature $\left(30^{\circ} \mathrm{C}\right)$, and low accumulate fluvial discharge inside Términos Lagoon $\left(2,828 \mathrm{~m}^{3} \mathrm{~s}^{-1}\right)$ because the rainy season is just beginning (Table 1, Fig. 3). After September, postlarvae entrance decreased when prevalent hydrological conditions were low salinity (28), a moderately warm lagoon temperature $\left(29^{\circ} \mathrm{C}\right)$ and high accumulate fluvial discharge $\left(3,934 \mathrm{~m}^{3}\right.$ $\mathrm{s}^{-1}$ ) because the rainy season ends, but the river discharge from the rivers continues due to runoff (Table 1, Fig. 3).

In contrast to our study, in the available literature, divisions of a complete postlarvae entrance cycle were not taken into account. For this reason, there was confusion in documenting correlations between postlarvae entrance, salinity and lagoon water temperature. Regarding salinity, Flores-Coto et al. (2018) and Gómez-Ponce et al. (2018) did not establish conclusions. Finally, adverse to our results, they mentioned that postlarvae entrance should increase during seasonal periods of low salinity. Gracia \& Soto (1990) indicated that most postlarvae entrance occurs between salinities of 22 and 34. Regarding lagoon water temperature, Gómez-Ponce et al. (2018) indicated that most postlarvae entrance occurs between 28.3 and $28.7^{\circ} \mathrm{C}$, while Flores-Coto et al. (2018) documented it from 29.7 to $30.8^{\circ} \mathrm{C}$. Gracia \& Soto (1990) reported lagoon water temperature results similar to those obtained in this study.
It should be taken into account that in Términos Lagoon, the second postlarvae entrance episode spawned in prevalent hydrological conditions: low salinity, a warm lagoon temperature and high accumulate fluvial discharge (Fig. 3). These hydrological conditions did not favor shrimp postlarvae entrance into lagoon systems (Figs. 2-3). According to the available bibliography (Cervantes-Hernández, 1999, 2015; Ramírez-Rodríguez et al., 2006; Cervantes-Hernández et al., 2012, 2017), these hydrological conditions are better at stimulating "lagoon recruitment" or the natural movement of shrimp postlarvae from the marine environment towards lagoon systems. For this reason, it should not be confused in which hydrological conditions lagoon recruitment occurs, and in which hydrological conditions immense postlarvae entrance occurs. Finally, in Términos Lagoon, the first postlarvae entrance episodes spawned in prevalent hydrological conditions: high salinity, warm lagoon temperature (Gracia \& Soto, 1990; Flores-Coto et al., 2018) and low accumulate fluvial discharge (Fig. 3).

\section{Marine spawner abundance changes}

As established, Gracia \& Soto (1990) reported a higher abundance of $P$. setiferus spawners in the Campeche Bank sector from October to February. Before 1993 it was similarly reported for $P$. duorarum (CervantesHernández \& Gracia, 2011) and P. aztecus in the Madre Lagoon, Tamaulipas-Veracruz sector, México (Cervantes-Hernández, 2015) (Fig. 4). In this last sector, studies on postlarvae entrance are not docu- 


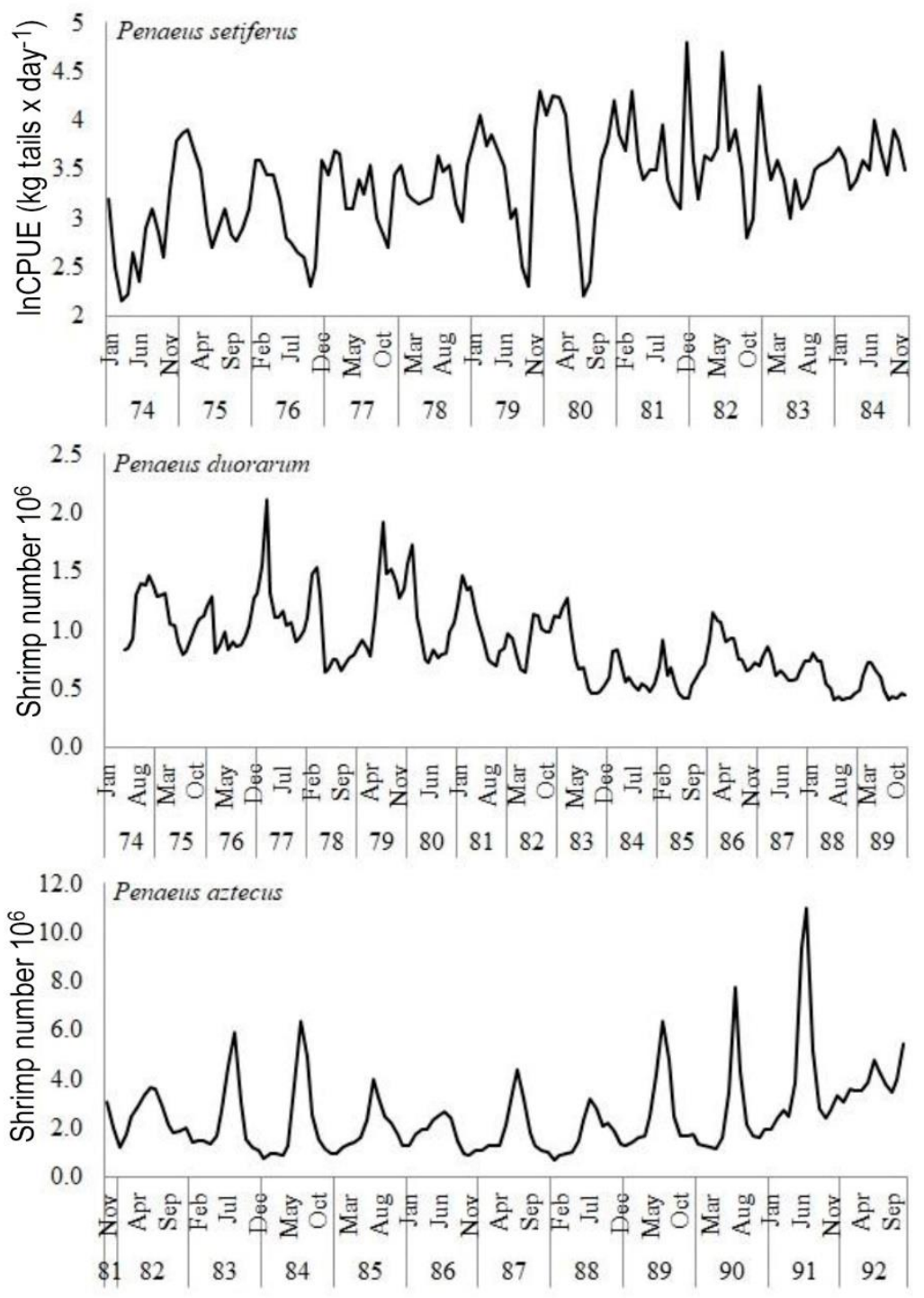

Figure 4. Three shrimp commercial catch time series. For Penaeus setiferus it is not known what age classes make up this information, but it was known that it included commercial categories of 10-25 tails per pound (Gracia, 1989). For $P$. duorarum commercial catch includes spawners between 8 and 16-month old (Cervantes-Hernández \& Gracia, 2011). For $P$. aztecus commercial catch includes spawners between 6 and 13 month old (Cervantes-Hernández, 2015). According to Gracia et al. (1997), the complete life cycle of the Penaeidae shrimp family is approximately between 15 and 18 month old. Sexual maturity is generally reached between 6 and 8 month old, but the entire population is sexually mature between 10 and 12 month old.

mented. For Campeche Bank sector reports on the winter presence of $P$. setiferus and $P$. duorarum, postlarvae cohorts were not found. In this study, we did not detect a cycle winter cycle.

In conclusion, it was demonstrated that postlarvae abundance did not occur in the season of maximum reproduction (winter months of December 2011 and January-February 2012) for both shrimp species. These were the fishing seasons. To explain this, we took into account the available literature and suggested the following explanation. Since 1993, after implemen- tation of closure seasons throughout the Gulf of México, fishing seasons have been mainly implemented from November/October to May (SAGARPAINP, 2012) (Fig. 4) and during this time fishing efforts quickly reduce shrimp spawner abundance in marine environments. Then as an immediate result, shrimp postlarvae abundance abruptly declines. So, the indicating signal of reproductive activity that we associate with postlarvae entrance became a weak undetectable signal inside Términos Lagoon. As was established in this study, the opposite occurs during closure seasons 
(from May to August with modifications until September/October), as fishing does not then affect shrimp spawner abundance, and as a result, shrimp postlarvae abundance does not collapse. So, then the indicating signal of reproductive activity can be detected inside Términos Lagoon.

Figure 4 shows the variation in the approximate number of winter shrimp spawners for $P$. setiferus (Gracia \& Soto, 1990) and P. duorarum (CervantesHernández \& Gracia, 2011) from October to February. Also, a complete $P$. aztecus reproductive season spawned from November to June, with the highest spawner abundance signal during February (CervantesHernández, 2015). Complementary studies conducted in the Araya Peninsula, Venezuela (Marval-Rodríguez et al., 2015), and the Gulf of Ana María, Cuba (Giménez-Hurtado et al., 2012), show that Farfantepenaeus notialis and $P$. duorarum generate winter cohorts.

Additionally, throughout the closure seasons from 1998-2002, SAGARPA-INP (2012) described the average presence of mature shrimp females in the Campeche Bank as between 10 and 33 per $\mathrm{km}^{2}$. This report suggests a lower presence of mature shrimp females during closure seasons than during the fishing seasons (Fig. 4), which is consistent with the following: in the Mexican Pacific, Cervantes-Hernández (2008) reported a higher percentage of egg-laying by $F$. californiensis mature females in phase IV from October to January. Also, the lowest percentage of egg-laying by $F$. californiensis mature females in phase IV was observed from July to September. Phase IV in shrimp of the genus Penaeus is characterized by dark-colored mature ovaries and an empty gonadal mass (SandovalQuintero \& Gracia, 1998).

In conclusion, it was demonstrated that the postlarvae abundance encountered in this study was not generated during the maximum reproductive seasons of both shrimp species, which should have occurred during winter when fishing seasons were implemented (Fig. 4).

Additional information on the reproductive activity of $P$. aztecus in the Tamaulipas and Veracruz sector indicates that annual reproductive seasons occur in winter oceanographic conditions of high Chl- $a$ levels $\left(>1.0 \mathrm{mg} \mathrm{m}^{-3}\right)$ and a colder sea surface temperature (SST $21-24^{\circ} \mathrm{C}$ ) (Cervantes-Hernández, 2015). The author mentioned that the Chl- $a$ presence is relevant because the trophic chain is activated from it, and larval stages of shrimp can feed directly on phytoplankton and zooplankton biomass. So, for $P$. aztecus, a high Chl- $a$ level means a greater degree of shrimp postlarvae survival due to the greater availability of its food. The aforementioned is evident from the immense shrimp postlarvae entrance inside Madre (Tamaulipas) and Tamiahua (Veracruz) lagoons.

Similar oceanographic conditions to those in the Tamaulipas and Veracruz sectors were documented during winter in the Campeche Bank sector. SalmerónGarcía et al. (2011) documented high Chl- $a$ levels $\left(>1.0 \mathrm{mg} \mathrm{m}^{-3}\right.$ ) between November and January, and low Chl- $a$ levels $\left(<1.0 \mathrm{mg} \mathrm{m}^{-3}\right)$ between April and November (1998-2008 period). The high Chl- $a$ level is associated with offshore transport caused by stronger wind during winter (like that which occurs in the Gulf of Tehuantepec), from December to January, while there is minimum wind impact in summer, from May and June (Romero-Centeno et al., 2003). Also, in the Gulf of Tehuantepec during winter upwelling seasons, oceanographic conditions of high Chl- $a$ levels $(>1.0 \mathrm{mg}$ $\left.\mathrm{m}^{-3}\right)$ and colder SST $\left(\sim 25-27^{\circ} \mathrm{C}\right)$ were recorded. There, during winter upwelling seasons, the highest abundance of $F$. californiensis spawners was reported (CervantesHernández et al., 2008). So, it should be taken into account that winter oceanographic conditions are better to stimulate spawning and increase shrimp postlarvae entrance into different lagoons. For this reason, we considered changes to closure season implementation.

We know that closure seasons are not entirely functional because Cervantes-Hernández \& Gracia (2011) reported the following monthly mortality balance: natural mortality $\mathrm{M}=0.21$, fishing mortality $\mathrm{F}$ $=0.25$, and total mortality $\mathrm{Z}=0.46$. The final balance was F > M, and based on this result, it was concluded that the population of $P$. duorarum was overfished from 1974-1989. Additionally, Cervantes-Hernández (2015) reported the following monthly mortality balance: $\mathrm{M}=$ $0.20, F=0.54, Z=0.74$. The final balance was $F>M$, and based on this result, it was concluded that the population of $F$. aztecus was overfished from 1974 to 1995.

Taking into account documented postlarvae abundance, we did not find evidence to demonstrate that closure seasons function effectively. When the study of Gracia \& Soto (1990) was conducted, fishing seasons were not delimited, and fishing efforts often affected the postlarvae abundance signal. For this reason, the authors reported lower shrimp postlarvae abundance with $P$. setiferus postlarvae dominant in all obtained samples $\left(4,743 \times 100 \mathrm{~m}^{-3}\right)$, while $P$. duorarum postlarvae were estimated at $817 \times 100 \mathrm{~m}^{-3}$. After the implementation of closure seasons, shrimp postlarvae abundance increased, maintaining the same abundance tendencies $\left(41,284\right.$ P. setiferus postlarvae $\times 100 \mathrm{~m}^{-3}$ and 37,558 P. duorarum postlarvae $\times 100 \mathrm{~m}^{-3}$ ) (FloresCoto et al., 2018). Similarly, low results were obtained in this study, considering the two postlarvae entrance episodes. On the other hand, in a study conducted in the 
Carmen and Machona lagoons, Tabasco, México, Flores-Coto et al. (2010) documented more P. setiferus postlarvae entrance $\left(13,332\right.$ for $\left.100 \mathrm{~m}^{-3}\right)$ than $F$. duorarum postlarvae entrance $\left(2,198\right.$ for $\left.100 \mathrm{~m}^{-3}\right)$.

In conclusion, the populations of $P$. setiferus and $P$. duorarum in the Campeche Bank sector have two recruitment and reproductive seasons throughout the whole year. The first occurs between the early and midrainy season (from June to September). The second occurs from early fall and during winter (from October to February).

\section{ACKNOWLEDGMENTS}

We thank the ICMyL UNAM for generated biological information and financing the project. We also thank UMAR for doctoral stay permission and Hernán Álvarez Guillén, Andrés Reda Deara, Alma Isabel Cima Cox, Derek J. Brockett and anonymous reviewers for comments that significantly improved the final version.

\section{REFERENCES}

Cervantes-Hernández, P. 1999. Relaciones stockreclutamiento del camarón rosado Farfantepenaeus duorarum (Burkenroad, 1939) en el Banco de Campeche. Tesis de Maestría, Universidad Nacional Autónoma de México, Ciudad de México, 35 pp.

Cervantes-Hernández, P. 2008. Method to obtain indices of abundance in the population of Farfantepenaeus californiensis from the Gulf of Tehuantepec, Oaxaca, México. Revista de Biología Marina y Oceanografía, 43(1): 111-119.

Cervantes-Hernández, P. 2015. Modelación de las fluctuaciones de la abundancia del camarón café Farfantepenaeus aztecus (Ives, 1891). Tesis Doctoral, Universidad Nacional Autónoma de México, Ciudad de México, 78 pp.

Cervantes-Hernández, P. \& Gracia, A. 2011. Análisis de la mortalidad para el camarón rosado Farfantepenaeus duorarum (Decapoda, Dendrobranchiata) del Banco de Campeche, México. Pan-American Journal of Aquatic Sciences, 6(2): 100-108.

Cervantes-Hernández, P., Gómez-Ponce, M.A. \& TorresHernández, P. 2012. Marine and lagoon recruitment of Litopenaeus vannamei Boone, 1931 (Decapoda: Penaeidae) in the "Cabeza de Toro-La Joya Buenavista" Lagoon System, Chiapas, México. CICIMAR Oceánides, 27(2): 51-58.

Cervantes-Hernández, P., Michel-Morfín, J.E. \& Gallardo-Berumen, M.I. 2016. Reproductive and recruitment seasons of the purple snail Plicopurpura pansa (Gould, 1853) in Oaxaca, México. Journal of Shellfish Research, 35(4): 993-1005.
Cervantes-Hernández, P., Torres-Hernández, P. \& Gómez-Ponce, M.A. 2017. Recruitment age of Litopenaeus vannamei (Boone, 1931) (Decapoda: Penaeidae) in the Cabeza de Toro-La Joya Buenavista Lagoon System, Oaxaca-Chiapas, México. Open Journal of Marine Science, 7: 511-525.

Cervantes-Hernández, P., Sánchez-Meraz, B., SerranoGuzmán, J.S., Frías-Velasco, A., Ramos-Cruz, S. \& Gracia, A. 2008. Variación interanual de la abundancia de Farfantepenaeus californiensis Holmes, 1900 en el Golfo de Tehuantepec. Hidrobiológica, 18(3): 215226.

Comisión Nacional de Acuacultura y Pesca (CONAPESCA). Data set. [http://www.conapesca.gob.mx/ wb/cona/informacion_estadistica_por_especie_y_enti dad]. Reviewed: June 08, 2018.

Flores-Coto, C. \& Zavala-García, F. 1994. Abundancia y distribución de larvas de Bregmacerotidae (Pisces) en la Bahía de Campeche, México. Ciencias Marinas, 20(2): 219-241.

Flores-Coto, C., Becerril-Martínez, J.A., Zavala-García, F., Gracia, A. \& Burke, J.S. 2010. Shrimp postlarvae immigration during the high current velocity period of the flood tide in the southern Gulf of México. Hidrobiológica, 20(1): 1-12.

Flores-Coto, C., Embriz-Alba, D., Gómez-Ponce, M.A., López-Martínez, J. \& Sanvicente-Añorve, L. 2018. Immigration of post larvae of penaeid shrimp to Términos Lagoon, Campeche, México: 2013 annual cycle. Open Journal of Marine Science, 8: 522-535.

Giménez-Hurtado, E., Alzugaray-Martínez, R., GarcésRodríguez, Y., Delgado-Miranda, G. \& VenturaFlores, A. 2012. Reclutamiento del camarón rosado Fafantepenaeus notialis (Decapoda: Penaeidae) en el Golfo de Ana María, Cuba. Serie Oceanológica, 10: 77-89.

Gómez-Ponce, M.A., Flores-Coto, C., López-Martínez, J., Cruz-Sánchez, J.L. \& Sanvicente-Añorve, L. 2018. Evaluation of the entry white shrimp postlarvae (Decapoda: Penaeidae) to a nursery area in the southern Gulf of México. Latin American Journal of Aquatic Research, 46(1): 166-175.

Gracia, A. 1989. Relationship between environmental factors and white shrimp abundance in the southwestern Gulf of México. Anales del Instituto de Ciencias del Mar y Limnología, 14: 171-182.

Gracia, A. 2004. Aprovechamiento y conservación del recurso camarón. In: Caso, M., Pisanty, M.I. \& Ezcurra, E. (Eds.). Diagnóstico ambiental del Golfo de México. SEMARNAT-Instituto Nacional de EcologíaHarte Research Institute for the Gulf of México Studies, Ciudad de México, pp. 713-725.

Gracia, A. \& Soto, L. 1990. Populations study of the penaeid shrimp of Términos Lagoon, Campeche, 
México. Anales del Instituto de Ciencias del Mar y Limnología, 17(2): 241-255.

Gracia, A., Vázquez-Bader, A.R., Arreguín-Sánchez, F., Schultz-Ruiz, L.E. \& Sánchez, J.A. 1997. Ecología de camarones peneidos. In: Flores-Hernández, D., Sánchez-Gil, P., Seijo, J.C. \& Arreguín-Sánchez, F. (Eds.). Análisis y diagnóstico de los recursos pesqueros críticos del Golfo de México. EPOMEX Serie Científica, Campeche, pp. 127-144.

Marval-Rodríguez, A., Altuve, D., Ramírez, I., Alió, J., Gómez, G., Cedeño, K., Martínez, F. \& Ortiz, L. 2015. Crecimiento y mortalidad de Farfantepenaeus notialis en la costa norte de la Península de Araya, Venezuela. Zootecnia Tropical, 33(3): 193-205.

Ramírez-Rodríguez, M., Arreguín-Sánchez, F. \& LluchBelda, D. 2006. Efecto de la temperatura superficial y la salinidad en el reclutamiento del camarón rosado Farfantepenaeus duorarum (Decapoda: Penaeidae), en la Sonda de Campeche, Golfo de México. Revista de Biología Tropical, 54(4): 1241-1245.

Ringo, R. \& Zamora, G. 1968. A penaeid postlarval caracter of taxonomic value. Bulletin of Marine Science, 18: 471-474.

Received: 29 July 2019; Accepted: 5 November 2019
Romero-Centeno, R., Zavala-Hidalgo, J., Gallegos, A. \& O'Brien, J.J. 2003. Isthmus of Tehuantepec wind climatology and ENSO signal. Journal of Climate, 16: 2628-2639.

Secretaría de Agricultura, Ganadería, Desarrollo Rural, Pesca y Alimentación - Instituto Nacional de Pesca (SAGARPA-INP). 2012. Dictamen técnico. Fundamento técnico para el establecimiento de vedas para la pesca de camarón en el Golfo de México y Mar Caribe. [https://www.inapesca.gob.mx/portal/documentos/bol sadetrabajo/2012/DICTAMENCAMARON2012_GM YMC.pdf]. Reviewed: June 10, 2018.

Salmerón-García, O., Zavala-Hidalgo, J., Mateos-Jasso, A. \& Romero-Centeno, R. 2011. Regionalization of the Gulf of México from space-time chlorophyll- $a$ concentration variability. Ocean Dynamics, 61: 439448.

Sandoval-Quintero, M.E. \& Gracia, A. 1998. Stages of gonadal development in the spotted pink shrimp Penaeus brasiliensis. Journal of Cell Biology, 18(4): 610-685.

Subrahmanyam, C.B. 1971. The relative abundance and distribution of penaeid shrimp larvae off the Mississippi coast. Gulf Research Reports, 3: 291-345. 